Anjumi dan Yaya, 2016

\title{
PENGARUH SISTEM PENGENDALIAN MANAJEMEN DAN KECERDASAN EMOSIONAL TERHADAP KINERJA STAFF ATC DENGAN LOCUS OF CONTROL SEBAGAI VARIABEL PEMODERASI \\ (Studi Kasus pada Perum LPPNPI AirNav Indonesia)
}

\author{
Fathul Huda Anjumi \\ Universitas Muhammadiyah Yogyakarta \\ Yogyakarta \\ Rizal Yaya \\ Universitas Muhammadiyah Yogyakarta \\ Yogyakarta \\ izalyaya@gmail.com
}

\begin{abstract}
The objective of this study is to analyze the effect of management control system and emotional intelligence on the performance of Air Traffic Controller (ATC) staffs with locus of control as a moderating variabel. This analysis used management control system and emotional intelligence as independent variables. The dependent variable is Performance of Air Traffic Controller. The samples used in this research are58 ATC staff with minimum education of Diploma 1 which was surveyed between 24 September to 5 November 2015. The statistical method used in this study is moderating regression analysis for the statistical test of hypothesis testing and statistical t test.Based on the analysis ofquestionnaires obtainedfound that the emotional intelligence hasa positive and significant impact on performance, while management control system does not have a significant effect on performance. Meanwhile in the statistical test by using locus of control as moderating variable, all independent variables have positive and significant influence.
\end{abstract}

Keywords : Air Traffic Controller; emotional intelligence; performance; locus of control; management control system.

\section{Pendahuluan}

Pengatur lalu lintas udara atau yang lebih dikenal dengan istilah Air Traffic Controller $(A T C)$ merupakan sebuah jenis pekerjaan yang hanya bisa dilakukan oleh ahli yang sebelumnya telah memperoleh pendidikan khusus setara Diploma 2. Seperti halnya akuntan publik, ATC juga mengalami proses sertifikasi yang berjalan ketat dan akan terus dicek dalam kurun waktu tertentu. Posisi ATC saat ini menjadi semakin berat karena minimnya sumber daya untuk mempermudah kerja mereka.Mulai dari kurangnya petugas ATC hampir di seluruh indonesia yang mencapai 800 orang hingga minimnya sistem navigasi yang terdapat di bandara-bandara yang tentunya akan menyebabkan peluang terjadinya kecelakaan tersebut menjadi meningkat.

Ditahun 2013 misalnya, radar yang ada di Bandara Internasional Adi Sutjipto, mengalami gangguan sebanyak tiga kali, yaitu pada bulan Januari, Juli dan September, dengan gangguan yang samayaitu pada sistem prosessornya (Setyawan, 2013).Kejadian tersebut membuat beberapa pesawat terbang terpaksa harus dipandu menggunakan visual manual menggunakan mata manusia.Hal tersebut tentunya sebuah resiko yang tetap harus diambil oleh ATC, padahal geografis disekitar Bandara Adisutcipto Yogyakarta terhitung ekstrim karena dikelilingi oleh gunung Merapi di sebelah utara dan perbukitan Wonosari disebelah timur dan tenggaranya. Hal selanjutnya yang menjadi tanggapan serius adalah ketika jalur penerbangan di langit Yogyakarta benarbenar sudah terlampau padat karena banyaknya pesawat latih milik TNI Angkatan Udara yang sedang mengitari bandara untuk melakukan pelatihan kepada para kadet muda mereka, disaat yang sama pesawat komersial yang rata-rata berpenumpang sekurang kurangnya 200 orang tiap pesawatnya mengantri dan melakukan manuver dengan berputar diatas langit kawasan Kulon Progo.

Sistem Pengendalian Manajemen atau SPM merupakan instrumen yang banyak digunakan oleh organisasi untuk meningkatkan kinerja finansial maupun non finansial organisasi.Kinerjajuga merupakan isu yang menjadi perhatian terhadap ATC saat ini.Kinerja mereka dituntut untuk selalu melakukan penilaian dan keputusan yang tepat disaat semua keterbatasan dan tekanan yang terjadi dilingkungan sekitar terhadap pekerjaan 
mereka.KinerjaATC merupakan suatu sistem formal dan terstruktur yang mengukur, menilai, dan mempengaruhi sifat-sifat yang berkaitan dengan pekerjaan, perilaku, dan hasil termasuk tingkat ketidakhadiran. Fokusnya adalah untuk mengetahui seberapa produktif seorang karyawan dan apakah ia bisa berkinerja sama atau lebih efektif pada masa yang akan datang, sehingga karyawan, organisasi, dan masyarakat semuanya memperoleh manfaat. Menurut data yang dihimpun oleh penulis, setidaknya 3 hingga 4 error atau kesalahan dapat terjadi di dunia penerbangan Indonesia ditarik dari jumlah bandara yang begitu banyak di indonesia. Namun hal tersebut masih tergolong tinggi karena industri penerbangan adalah industri dimana tidak boleh terjadinya kecelakaan sekecil apapun itu karena berkaitan dengan keselamatan manusia.

Penelitian ini terinspirasi dari penelitian yang dilakukan oleh Budiman, dkk (2013).Kontribusi penelitian ini yaituuntuk mengetahui seberapa besar tuntutan pekerjaan yang dialami ATC serta mengetahui probabilitas terjadinya error kerja. Kemudian dilakukan identifikasi analisis risiko bahaya yang ada pada pekerjaan ATC berdasarkan hasil pengamatan.Berdasarkan penelitian sebelumnya pengaruh terbesar pada pekerjaan ATC adalah kebutuhan mental, dan performansi, sedangkan kebutuhan fisik bernilai sangat kecil dibandingkan dimensi lainnya.Sehingga diketahui bahwa pekerjaan ATC memiliki beban kerja mental yang cukup besar.Hal ini membuktikan bahwa profesi ATC memiliki tingkat resiko dan tanggung jawab yang besar.

\section{Kajian Literatur dan Pengembangan Hipotesis}

Keberhasilan suatu organisasi dalam mencapai tujuan dan memenuhi tanggung jawab sosialnya, sebagian besar tergantung pada manajer. Apabila manajer mampu melakukan tugas-tugasnya dengan baik, maka organisasi akan mampu mencapai sasaran dan tujuan yang dikehendaki. Bernardin dan Russel (1993) memberikan pengertian kinerja sebagai berikut : "Performance is defined as the record of outcomes produced on a specified job function or activity during time period". Prestasi atau kinerja adalah catatan tentang hasil-hasil yang diperoleh dari fungsi-fungsi pekerjaan tertentu atau kegiatan selama kurun waktu tertentu. Kinerja utamanya menentukan masa hidup suatu perusahaan, jika kinerja yang ditunjukan suatu perusahaan selalu dalam tren yang positive atau meskipun hanya stabil perusahaan masih memiliki masa depan untuk melanjutkan kegiatan usahanya.Pengertian kinerja lainnya dikemukakan oleh Simanjuntak (2005:1) mengemukakan bahwa kinerja adalah tingkat pencapaian hasil atas pelaksanaan tugas tertentu. Kinerja perusahaan adalah tingkat pencapaian hasil dalam rangka mewujudkan tujuan perusahaan. Manajemen kinerja adalah keseluruhan kegiatan yang dilakukan untuk meningkatkan kinerja perusahaan atau organisasi, termasuk kinerja masing-masing individu dan kelompok kerja di perusahaan tersebut.Untuk memastikan tercapainya kinerja yang diharapkan, suatu organisasi mengembangkan sistem pengendalian manajemen yang baik.

Sistem pengendalian manajemendigunakan memberi motivasi anggota organisasi agar bertindak dan dapat membuat keputusan secara konsisten dengan tujuan organisasi (Kren, 1992).Seperti dalam penelitian sebelumnya yang dikemukakan oleh Sabeni dan Wiyantoro (2007),sistem pengendalian manajemen merupakan alat untuk memonitor atau mengamati pelaksanaan manajemen perusahaan yang mencoba mengarahkan pada tujuan organisasi dalam perusahaan agar kinerja yang dilakukan oleh pihak manajemen perusahaan dapat berjalan lebih efisien dan lancar.Menurut Fisher (1995) sistem pengendalian manajemen dipengaruhi oleh faktor kontinjensi seperti budaya dan struktur perusahaan yang secara tidak langsung berhubungan dengan sistem pengendalian manajemen.Faktor kontinjensi tersebut dapat memoderasi hubungan antara variabel yang salah satunya adalah budaya nasional.Dalam penelitian sebelumnya Birnberg dan Snodgrass (1983) meneliti pengaruh budaya nasional terhadap sistem pengendalian manajemen sedangkan penelitian yang dilakukan Chow et.al (1999) meneliti peranan budaya nasional dalam desain dan kinerja terhadap pengendalian manajemen.

Salovey and Mayer (1990) memperkenalkan konsep dari Emotional Intelegencia (EI) sebagai salah satu bagian dari kecerdasan sosial, terpisah dari kecerdasan umum. Berdasarkan pernyataan tersebut, EI merupakan perilaku satu orang dan lainnya, untuk membedakan diantara keduanya, dan serta untuk mempergunakan informasi untuk menjadi panduan pemikiran seseorang dan menjadikannya tindakan. Penelitian telah menunjukkan bahwa EI yang dilakukan oleh Modassir (2008) adalah elemen umum yang mempengaruhi cara yang berbeda dalam mengembangkan pribadi seseorang dalam kehidupan, pekerjaan, dan keterampilan sosial mereka; menangani frustrasi; mengontrol mereka emosi; dan bergaul dengan orang lain.Barling et.al (2000) mencatat bahwa EI terdiri dari lima karakteristik: (1) memahami emosi seseorang; (2) mengetahui bagaimana mengelola mereka; (3) emosional kontrol diri, yang mencakup kemampuan untuk menunda kepuasan; memahami emosi orang lain atau empati; dan mengelola hubungan. Goleman (2002) membagi 18 kompetensi EI menjadi empat kelompok utama yang mencakup 
pemahaman kita tentang orang: kesadaran diri, manajemen diri, kesadaran sosial, dan manajemen hubungan.

Kecerdasan Emosional dianggap penting karena EI memungkinkan orang untuk menangani apa saja dengan ukuran keseimbangan dan jatuh tempo. Emosional orang-orang cerdas memiliki rasa yang mendalam berakar dari diri yang membantu mereka dalam memahami orang lain, menjaga hal-hal dalam proporsi, mempertahankan fokus, dan pemahaman apa yang penting. Mereka juga mempertahankan sudut pandang positif hampir sepanjang waktu, berhasil dalam apa pun yang mereka memilih untuk melakukan, memiliki kinerja kerja yang tinggi dan tingkat produktivitas pribadi, dan akibatnya menikmati kepuasan kerja yang lebih besar.

Teori atribusi berkaitan dengan bagaimana individu menginterpretasikan peristiwa-peristiwa dan bagaimana ini berkaitan dengan pemikiran mereka dan perilaku. Teori Atribusi mengasumsikan bahwa orang mencoba untuk menentukan mengapa orang melakukan apa yang mereka lakukan. Seseorang berusaha untuk memahami mengapa orang lain melakukan sesuatu yang mungkin satu atau lebih atribut menyebabkan perilaku itu. Menurut Heider, (1958) seseorang dapat membuat dua atribusi: 1) Atribusi Internal, kesimpulan bahwa seseorang berperilaku dalam cara tertentu karena sesuatu tentang orang, seperti sikap, karakter atau kepribadian. 2) Atribusi Eksternal, kesimpulan bahwa seseorang berperilaku dengan cara tertentu karena sesuatu tentang situasi dia masuk.Atribusi internal antara lain adalah persepsi individu terhadap Locus of Control, sedangkan atribusi eksternal antara lain konstruksi sosial yang memandang peran yang diterima seseorang berdasarkan jenis kelamin, sebagai akibat perspektif yang terbentuk dalam sosial.Teori ini digunakan untuk menilai atribusi perilaku eksternal ATC dalam kaitannya dengan stres kerja serta locus of control.

\section{Sistem Pengendalian Manajemen terhadap Kinerja}

Sistem pengendalian manajemen pada dasarnya merupakan salah satu cara yang dilakukan para manajer dalam memastikan karyawan dapat terus melaksanakan tugas sesuai dengan jalur untuk mencapai tujuan. Seperti dalam penelitian sebelumnya yang dikemukakan oleh Sabeni dan Wiyantoro (2007) menunjukan bahwa SPM berkaitan dengan budaya organisasi mengimplikasi karyawan dalam membuat Kinerja menjadi lebih baik.

Penelitian tersebut didukung oleh Penelitian yang dilakukan oleh Chow et.al (1999) menunjukkan bahwa budaya nasional mempengaruhi desain perusahaan dan kinerja karyawan terhadap pengendalian manajemen. Secara teoritikal Chow et.al
(1999) menemukan bahwa budaya sebagai dasar penelitian dalam pengendalian manajemen. Kami meyakini bahwa SPM dapat berpengaruh positif terhadap kinerja karena kinerja yang baik dari suatu organisasi timbul karena adanya keteraturan dan lingkungan yang terjamin bagi kegiatan perusahaan. Dari uraian tersebut peneliti dapat menyimpulkan hipotesis yang pertama yaitu

$\mathrm{H}_{1}$ : Sistem pengendalian manajemen berpengaruh positif terhadap kinerja ATC di Perum LPPNPI Airnav Indonesia

\section{Kecerdasan Emosional terhadap Kinerja}

Penelitian sebelumnya yang dilakukan Modassir (2008) menunjukan bahwa Organization Citizenship Behaviour (OCB) yang merupakan bagian dari Emotional Intelligent, OCB membantu pengembangan dan pemeliharaan modal sosial dalam perusahaan, yang pada gilirannya menghasilkan tingkat yang lebih tinggi dari kinerja organisasi. Organizational Citizenship Behavior (OCB) merupakan perilaku individu yang ekstra, yang tidak secara langsung atau eksplisit dapat dikenali dalam suatu sistem kerja yang formal, dan yang secara agregat mampu meningkatkan efektivitas fungsi organisasi (Organ, 1988). OCB juga dapat berkontribusi pada pengembangan kepercayaan, saling kewajiban, harapan, dan identifikasi antara karyawan dalam organisasi.

Terutama dalam hal mengenali emosi diri, mengelola emosi, memotivasi diri sendiri, mengenali emosi orang lain, dan membina hubungan dengan orang lain kecerdasan emosional pribadi sudah terbentuk. Sedangkan berkenaan dengan kinerja, kesimpulan tersebut memberikan gambaran bahwa karyawan pada umumnya memiliki kemampuan yang baik dalam menjalankan tugasnya terutama dalam hal kecepatan, kualitas, layanan, nilai, keterampilan interpersonal, mental sukses, keterbukaan untuk berubah, kreativitas, keterampilan berkomunikasi, inisiatif, dan perencanaan organisasi. Selanjutnya, diketahui bahwa kecerdasan emosional memiliki hubungan positif dan signifikan dengan kinerja karyawan. Menurut penelitian sebelumnya oleh (Univ Azzahra, 2013) Apabila kondisi kecerdasan emosional menurun, dengan asumsi faktor lainnya dalam kondisi cateris paribus, maka akan mengakibatkan penurunan kinerja karyawan, dan sebaliknya apabila kondisi kecerdasan emosional karyawan semakin baik, dengan asumsi faktor lainnya juga dalam kondisi cateris paribus, maka akan mengakibatkan meningkatnya kinerja karyawan. Dari uraian tersebut peneliti dapat menyimpulkan hipotesis yang keduayaitu :

$\mathrm{H}_{2}$ : Kecerdasan Emosional berpengaruh positif terhadap Kinerja di Perum LPPNPI Airnav Indonesia 


\section{Locus of control mempengaruhi antara Kecerdasan Emosional, SPM dan Kinerja}

Menurut Baron dan Byrne (1994) locus of control diartikan sebagai persepsi sesorang tentang sebab-sebab keberhasilan atau kegagalan dalam melaksanakan pekerjaannya. Locus of control dibedakan menjadi lokus kontrol internal (internal locus of control) dan lokus kontrol eksternal (external locus of control). Kontrol internal akan tampak melalui kemampuan kerja dan tindakan kerja yang berhubungan dengan keberhasilan dan kegagalan karyawan pada saat melakukan pekerjaannya. Sedangkan karyawan dengan kontrol eksternal merasakan bahwa terdapat kontrol di luar dirinya yang mendukung hasil pekerjaan yang dilakukan.

Penelitian yang dilakukan oleh Suryani (2005) pada auditor yang bekerja di kantor IV BPK Yogyakarta menunjukkan bahwa ada interaksi antara gaya kepemimpinan directive dan locus of control terhadap kepuasan kerja. Penelitian yang dilakukan oleh Hening (1998) dan Basri (2005) juga menunjukkan bahwa adanya hubungan yang signifikan antara gaya kepemimpinan dan kepuasan kerja melalui locus of control sebagai variabel pemoderasi.

Berdasarkan penelitian yang dilakukan oleh (Eka : 2010), membuktikan bahwa semakin kuat locus of control maka akan semakin kuat kinerja karyawan, hal tersebut di dukung oleh uji Nilai $\mathrm{P}$ value yang kurang dari 0,05 dapat ditarik disimpulkan bahwa variabel bebas locus of control secara parsial berpengaruh positif dan signifikan terhadap variabel terikat kinerja karyawan.

Dari uraian tersebut peneliti dapat menyimpulkan hipotesis yang kedua yaitu :

$\mathrm{H}_{3}$ : Locus Of Control berpengaruh terhadap hubungan antara sistem pengendalian manajemen terhadap kinerja.

$\mathrm{H}_{4}$ : Locus Of Control berpengaruh terhadap hubungan Kecerdasan Emosional terhadap kinerja.

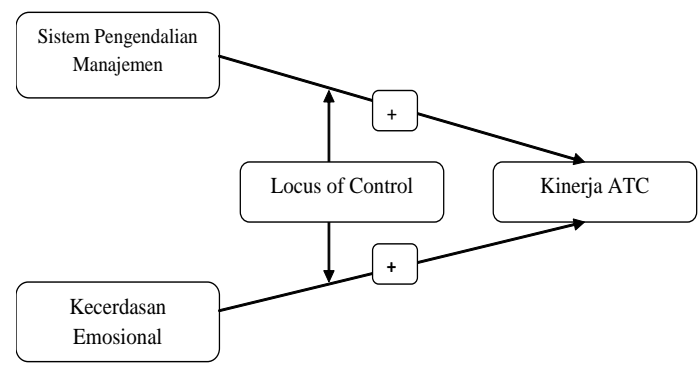

Gambar 1

Model Penelitian

\section{Metode Penelitian}

Objek/Subjek Penelitian

Subyek penilitian ini merupakan karyawan di Perum LPPNPI Airnav Indonesia yang menjadi sebagai sample bertugas sebagai ATC. Petugas ATC yang kami jadikan subyek berasal dari bandara Adisutcipto Yogyakarta, bandara Sepinggan Balikpapan dan bandara Ahmad Yani Semarang. Peneliti mengambil ketiga populasi tersebut karena terdapat kemiripan karakteristik ketiganya.

\section{Jenis dan teknik pengumpulan data}

Penelitian ini adalah penelitian kuantitatif, serta jenis data pada penelitian ini adalah data primer.Data untuk penelitian ini dikumpulkan dengan menggunakan kuesioner, yaitu sejumlah pertanyaan tertulis yang digunakan untuk memperoleh informasi dari responden berupa pandangan responden mengenai kinerja yang telah mereka lakukan serta pandangan mereka mengenai kondisi pelayanan jasa udara di bandara tersebut. Kuisioner tersebut akan dibagikan langsung oleh peneliti kepada responden.

Metode selanjutnya yang akan dilaksanakan oleh peneliti adalah dengan observasi lapangan dengan mengunjungi langsung bandara yang dijadikan sample, kemudian akan dilakukan pengamatan mengenai reaksi dan tingkat kesalahan ATC di bandara setempat dalam periode waktu yang sama antara tiap sample. Untuk pemahaman lebih dalam terhadap jawaban yang diperoleh melalui kuesioner, peneliti juga melakukan interview semi-struktur dengan beberapa staf dan pimpinan di ATC.

\section{Teknik Pengambilan Sampel}

Populasi dalam penelitian ini adalah semua bandara internasional yang terdapat di Indonesia sebanyak 32 buah.Teknik pengambilan sampel dari penelitian ini adalah denganpendekatan metode convenience sampling ke ATC yang relative mudah peneliti akses.Dalam hal ini ada tiga ATC yaitu Yogyakarta, Semarang dan Balikpapan.Metode convenience sampling juga digunakan dalam memilih responden staf ATC untuk mengisi kuesioner penelitian.Dari 80 kuesioner yang didistribusikan, terdapat 58 kuesioner yang kembali dan dapat digunakan untuk analisis.Adapun untuk interview dipilih beberapa staf yang dianggap sebagai representasi beberapa karakter staf ATC yang ada.

\section{Definisi Operasional Variabel Penelitian}

1. Kinerja ATC

Kinerja pada dasarnya merupakan sesuatu hal yang cukup sulit untuk ditentukan, terutama jika kinerja tersebut tidak berhubungan dengan hasil yang nyata seperti yang dilakukan 
para responden kami. Kinerja adalah hasil yang dicapai dari suatu kegiatan atau usaha yang dapat memberikan kepuasan emosional, dan data diukur dengan alat atau tes tertentu. Dalam proses penilaian kinerja data diartikan sebagai hasil dari proses belajar mengajar yakni, penguasaan, perubahan emosional, atau perubahan tingkah laku yang dapat diukur dengan tes tertentu.

Dalam mengukur variabel kinerja, responden akan dimintai pendapatnya mengenai perencanaan, penyelidikan, koordinasi, serta pengawasan. Variabel kinerja diukur menggunakan kuisioner Bonavantura Dinar dengan skala likert 5 point dengan point terendah 1 = tidak penting dan point 5 tertinggi (sangat penting). Apabila responden menjawab 1 yang menunjukkan kinerja responden tersebut rendah sedangkan jika responden menjawab 5 berarti kinerja responden tinggi/memuaskan.

\section{Sistem Pengendalian Managemen}

Sistem pengendalian manajemen merupakan alat untuk memonitor atau mengamati pelaksanaan manajemen perusahaan yang mencoba mengarahkan pada tujuan organisasi dalam perusahaan agar kinerja yang dilakukan oleh pihak manajemen perusahaan dapat berjalan lebih efesien dan lancer, Yang dimonitor atau yang diatur dalam sistem pengendalian manajemen adalah kinerja dari perilaku manajer di dalam mengelola perusahaan yang akan dipertanggungjawabkan kepada stakeholders

Dalam mengukur variabel Sistem Pengendalian Managemen, responden akan dimintai pendapatnya mengenai organisasi, tanggung jawab, prosedur kerja dan sistem pelaporan.Variabel SPM diukur menggunakan kuisioner Wiyantoro (2007) dengan skala likert 5 point dengan point terendah $1=$ tidak penting dan point 5 tertinggi ( sangat penting). Apabila responden menjawab 1 yang menunjukkan tingkat pemahaman responden terhadap SPM tersebut rendah sedangkan jika responden menjawab 5 berarti tingkat pemahaman responden terhadap SPM tinggi.

\section{Kecerdasan Emosional}

Kecerdasan Emosional dianggap penting karena EI memungkinkan orang untuk menangani apa saja dengan ukuran keseimbangan dan jatuh tempo. Emosional orang-orang cerdas memiliki rasa yang mendalam berakar dari diri yang membantu mereka dalam memahami orang lain, menjaga hal-hal dalam proporsi, mempertahankan fokus, dan pemahaman apa yang penting.
Dalam mengukur variabel kinerja, responden akan dimintai pendapatnya mengenai hubungan antara karyawan, kemampuan kerja dan sosialisasi dengan sekitar.Variabel EI diukur menggunakan kuisioner Bonavantura Dinar dengan skala likert 5 point dengan point terendah $1=$ tidak penting dan point 5 tertinggi (sangat penting). Apabila responden menjawab 1 yang menunjukkan tingkat kecerdasan secara emosional responden tersebut rendah sedangkan jika responden menjawab 5 berarti tingkat kecerdasan secara emosional tinggi/memuaskan.

\section{Uji Hipotesis dan Analisa Data}

Analisis regresi digunakan untuk memberikan jawaban mengenai besarnya pengaruh variabel independen terhadap variabel dependen. Analisis regresi digunakan oleh peneliti apabila peneliti bermaksud meramalkan bagaimana keadaan (naikturunnya) variabel dependen, dan apabila dua atau lebih variabel independen sebagai prediktor dimanipulasi atau dinaikturunkan nilainya (Sugiyono,2009). Analisis regresi berganda digunakan untuk memecahkan masalah dalam peneltian dengan model regresi linear berganda sebagai berikut :

Untuk Hipotesis Pertama dan Kedua dijelaskan melalui persamaan berikut :

$$
\mathrm{Y}=\alpha+\beta_{1} \mathrm{SPM}+\beta_{2} \mathrm{KE}+\beta_{3} \mathrm{LOC}+\varepsilon
$$

Untuk Hipotesis Kedua dan Ketiga dengan Locus of Control sebagai Pemoderasi dijelaskan melalui persamaan berikut :

$\mathrm{Y}=\alpha+\beta_{1} \mathrm{SPM}+\beta_{2} \mathrm{KE}+\beta_{3} \mathrm{KELOC}+\mathrm{e}$

$\mathrm{Y}=\alpha+\beta_{1} \mathrm{SPM}+\beta_{2} \mathrm{KE}+\beta_{3} \mathrm{SPMLOC}+\mathrm{e}$

Dimana :

$\mathrm{Y}=$ Kinerja

LOC $=$ Locus of Control

$\alpha=$ Konstanta

$\beta_{1}=$ koefisien regresi untuk $X_{1}$

$\beta_{2}=$ koefisien regresi untuk $X_{2}$

$\beta_{3}=$ koefisien regresi untuk $X_{3}$

$\mathrm{e}=$ faktor pengganggu

\section{Analisis Regresi}

a) Uji Signifikansi Nilai t

Uji statistik $t$ pada dasarnya menunjukkan seberapa jauh pengaruh satu variabel independen secara individual dalam menerangkan variasi variabel dependen. Pengujian dilakukan dengan menggunakan significance level $0,05(\alpha=5 \%)$. Hipotesis akan didukung apabila koefisien $\beta_{1} ; \beta_{2} ; \beta_{3} ; \beta_{4}$; bernilai positif dan Pvalue $<\alpha(0,05)$.

b) Uji koefisien determinasi (Adjusted $R^{2}$ ) 
Uji koefisien determinasi dilakukan untuk melihat kemampuan variabel independen dalam menjelaskan variasi perubahan variabel dependen. Koefisien determinasi dapat dilihat dari nilai Adjusted $R^{2}$ dimana untuk menginterpretasikan besarnya nilai koefisien determinasi harus diubah dalam bentuk presentase, kemudian sisanya (100\%-persentase koefisien determinasi) dijelaskan oleh variabel lain yang tidak masuk dalam model.

c) Uji Simultan (Nilai F)

Uji nilai $\mathrm{F}$ dilakukan untuk melihat pengaruh variabel independen terhadap variabel dependen secara bersama-sama. Pengujian ini dilakukan dengan menggunakan nilai sig, yaitu hipotesis diterima atau terdapat pengaruh secara bersamasama jika sig $<\alpha(0,05)$, dan hipotesis ditolak apabila nilai sig $>\alpha(0,05)$.

\section{Hasil dan Pembahasan}

Gambaran umum responden penelitian

Kuesioner penelitian ini mulai disebar tanggal 24 September 2015 dan terkumpul kembali pada tanggal 5 November 2015. Tingkat pengembalian kuesioner dapat digambarkan seperti tabel 1 berikut:

Tabel 1: Tingkat Pengembalian Kuesioner

\begin{tabular}{|l|c|c|}
\hline Kuesioner & Jumlah & Persentase \\
\hline $\begin{array}{l}\text { Kuesioner yang } \\
\text { disebar }\end{array}$ & 80 & $100 \%$ \\
\hline $\begin{array}{l}\text { Kuesioner yang } \\
\text { kembali }\end{array}$ & 64 & $80 \%$ \\
\hline $\begin{array}{l}\text { Kuesioner yang tidak } \\
\text { kembali }\end{array}$ & 16 & $20 \%$ \\
\hline $\begin{array}{l}\text { Kuesioner yang tidak } \\
\text { dapat dianalisis }\end{array}$ & 6 & $7,5 \%$ \\
\hline $\begin{array}{l}\text { Kuesioner yang dapat } \\
\text { dianalisis }\end{array}$ & 58 & $72,5 \%$ \\
\hline
\end{tabular}

Berdasarkan tabel di atas dapat disimpulkan bahwa kuesioner yang disebar sebanyak 80 buah atau sebesar $100 \%$. Kuesioner yang kembali sebanyak 64 buah atau sebesar $80 \%$. Kuesioner yang tidak kembali sebanyak 16 buah atau sebesar 19\%. Berdasarkan identifikasi terkahir ditemukan kuesioner yang tidak layak untuk di analisis sebanyak 6 buah yang disaring menggunakan metode casewise.

Pada tabel 2 di dapat diketahui responden laki-laki berjumlah 32 orang $(55,17 \%)$, untuk responden perempuan berjumlah 26 orang $(44,83 \%)$. Untuk responden berdasarkan jenjang pendidikan, didapatkan bahwa responden yang jenjang pendidikan D1 berjumlah 0 orang $(0 \%)$, sedangkan responden yang jenjang pendidikan jenjang pendidikan D2 berjumlah 3 orang $(5,10 \%)$, jenjang pendidikan D3 berjumlah 27 orang $(46,55 \%)$, sementara untuk jenjang pendidikan Strata 1 berjumlah 14 orang $(24,13 \%)$, sementara lainnya 14 orang $(24,13 \%)$.

Tabel 2: Karakteristik Responden

\begin{tabular}{|c|c|c|}
\hline Keterangan & Jumlah & $\begin{array}{c}\text { Persentase } \\
(\%)\end{array}$ \\
\hline $\begin{array}{cc}\text { Jenis } & \text { Kelamin } \\
- & \text { Laki-Laki } \\
- & \text { Perempuan }\end{array}$ & $\begin{array}{l}32 \\
26\end{array}$ & $\begin{array}{l}55,17 \\
44,83\end{array}$ \\
\hline $\begin{array}{cl}\text { Jenjang } & \text { Pendidikan } \\
- & \text { Diploma } 1 \\
- & \text { Diploma 2 } \\
\text { - } & \text { Diploma } 3 \\
\text { - } & \text { Strata 1 } \\
- & \text { Lainnya } \\
\end{array}$ & $\begin{array}{c}0 \\
3 \\
27 \\
14 \\
14\end{array}$ & $\begin{array}{c}0 \\
5,10 \\
46,55 \\
24,13 \\
24,13\end{array}$ \\
\hline $\begin{aligned} & \text { Tingkat Pelatihan } \\
&- \text { Area Controller } \\
&- \text { Approach } \\
& \text { Controller } \\
&- \text { Aerodrome } \\
& \text { Contr } \\
&- \text { ATC Student } \\
&- \text { Supervisor } \\
&- \text { Lainnya }\end{aligned}$ & $\begin{array}{c}0 \\
20 \\
14\end{array}$ & $\begin{array}{c}0 \\
34,48 \\
24,13 \\
1,55\end{array}$ \\
\hline
\end{tabular}

Tingkat pelatihan menentukan seberapa senior dan seberapa tinggi tingkatan individu masing-masing ATC dalam mengelola lalu lintas udara, atas dasar itu diketahui sbb : Area Controller 0 orang $(0,00 \%)$, Approach Controller 20 orang (34,48\%), Aerodrome Controller 14 orang $(24,13 \%)$, Atc student 9 orang $(1,55 \%)$, Supervisor 2 orang $(3,44 \%)$, serta lainnya berjumlah 12 orang $(20,68 \%)$.

\section{Statistik Deskriptif}

Variabel yang digunakan dalam penelitian ini meliputi Sistem Pengendalian Manajemen, Kecerdasan Emosional,Locus of Control,sertaKinerja yang akan diuji secara deskriptif seperti yang terlihat pada tabel 3 berikut :

Tabel 3: Hasil Uji Statistik Deskriptif

\begin{tabular}{|l|l|r|r|r|r|}
\hline & & \multicolumn{1}{|c|}{$\begin{array}{c}\text { Minimu } \\
\mathrm{m}\end{array}$} & $\begin{array}{c}\text { Maximu } \\
\mathrm{m}\end{array}$ & $\begin{array}{c}\text { Mea } \\
\mathrm{n}\end{array}$ & $\begin{array}{c}\text { Std. } \\
\text { Deviatio } \\
\mathrm{n}\end{array}$ \\
\hline TOTAL_KE & 5 & 34 & 59 & 48,0 & 4,464 \\
& 8 & & & 3 & \\
TOTAL_SP & 5 & 32 & 55 & 43,5 & 4,635 \\
M & 8 & & & 0 & \\
TOTAL_LO & 5 & 30 & 50 & 38,3 & 4,825 \\
C & 8 & & & 4 & \\
TOTAL_P & 5 & 23 & 35 & 30,4 & 3,255 \\
& 8 & & & 0 &
\end{tabular}


Tabel 3: Hasil Uji Statistik Deskriptif

\begin{tabular}{|c|c|c|c|c|c|}
\hline & $\mathrm{N}$ & $\begin{array}{c}\text { Minimu } \\
\mathrm{m}\end{array}$ & $\begin{array}{c}\text { Maximu } \\
\mathrm{m}\end{array}$ & $\begin{array}{c}\text { Mea } \\
\mathrm{n}\end{array}$ & \begin{tabular}{|c|} 
Std. \\
Deviatio \\
n
\end{tabular} \\
\hline TOTAL_KE & \begin{tabular}{|l|}
5 \\
8 \\
\end{tabular} & 34 & 59 & $\begin{array}{r}48,0 \\
3\end{array}$ & 4,464 \\
\hline $\begin{array}{l}\text { TOTAL_SP } \\
\text { M }\end{array}$ & $\begin{array}{l}5 \\
8\end{array}$ & 32 & 55 & $\begin{array}{r}43,5 \\
0\end{array}$ & 4,635 \\
\hline $\begin{array}{l}\text { TOTAL_LO } \\
\text { C }\end{array}$ & $\begin{array}{l}5 \\
8\end{array}$ & 30 & 50 & $\begin{array}{r}38,3 \\
4\end{array}$ & 4,825 \\
\hline $\begin{array}{l}\text { TOTAL_P } \\
\text { Valid N } \\
\text { (listwise) }\end{array}$ & $\begin{array}{l}5 \\
8 \\
5 \\
8\end{array}$ & 23 & 35 & $\begin{array}{r}30,4 \\
0\end{array}$ & 3,255 \\
\hline
\end{tabular}

Dari hasil yang diperoleh dengan jumlah responden sebanyak 58 orang, jawaban responden cukup bervariasi dengan skor jawaban responden untuk variabel Kinerja (P) berkisar antara 23 sampai dengan 35 , dari data responden rata-rata untuk semua adalah 30,40 dengan standar deviasi 3,255. Sedangkan Sistem Pengendalian Manajemen $\left(\mathrm{X}_{1}\right)$ memiliki skor berkisar 32 sampai dengan 55 dengan rata-rata 43,50 dengan standar deviasi sebesar 4,635. Kemudian variabel Kecerdasan Emosional $\left(\mathrm{X}_{2}\right)$, nilai terendah adalah 34 sedangkan nilai tertinggi adalah 55 dan nilai rata-rata (mean) adalah 48,03 dengan standar deviasi sebesar 4,464 untuk variableLocus of Control $\left(\mathrm{X}_{3}\right)$ dengan skor jawaban responden yang berkisar antara 30 sampai dengan 50, dengan rata-rata jawaban responden sebesar 38,34 dan standar deviasi dengan 4,825 .

Berdasarkan hasil uji statistik deskriptif di atas dapat disimpulkan bahwa rata-rata jawaban responden untuk Sistem Pengendalian Manajemen, Kecerdasan Emosional, Locus of Control,sertaKinerja adalah setuju.

\section{Uji Kualitas Instrumen dan Data}

\section{Uji Validitas dan reliabilitas}

Uji validitas digunakan untuk mengukur valid atau tidaknya suatu kuesioner.Pengujian ini dilakukan dengan menggunakan Pearson Corelation, pedoman suatu model dikatakan valid jika tingkat signifikansinya dibawah 0.05 , maka butir pertanyaan tersebut dapat dikatakan valid (Ghozali,2009). Dari hasil output dapat seluruh butir pertanyaan untuk semua variabelmemiliki kriteria valid dan nilai signifikansi di bawah 0.05 , maka dapat disimpulkan seluruh butir pertanyaan adalah valid.

Uji reliabilitas dilakukan untuk menilai konsistensi dari instrumen penelitian.Suatu instrumen penelitian dapat dikatakan reliabel jika nilai Cronbach Alpha berada diatas 0.60 (Ghozali,2009).Berdasarkan hasil pengujian reliabilitas variabel Sistem Pengendalian Manajemen, Kecerdasan Emosional, Locus of Control, serta Kinerja, didapat nilai cronbach's alpha variabel Sistem Pengendalian Manajemen adalah sebesar 0.826, Kecerdasan Emosional sebesar 0.738, Locus of Controlsebesar 0.776, danKinerja sebesar 0.901.Dengan demikian, dapat disimpulkan bahwa pernyataan dalam kuesioner ini reliabel karena mempunyai nilai cronbach's alpha lebih besar dari 0.60. Hal ini menunjukkan bahwa setiap butir pernyataan yang digunakan mampu memperoleh data yang konsisten, yang berarti bila pernyataan itu diajukan kembali akan diperoleh jawaban yang relatif sama dengan jawaban sebelumnya.

\section{Uji Asumsi Klasik}

Uji normalitas pada penelitian ini menggunakan pendekatan Normal Probability Plot (P-Plot), model regresi layak digunakan karena memenuhi asumsi normalitas. Hal ini dibuktikan dengan terjadinya penyebaran data (titik-titik) disekitar garis regresi (garis diagonal).untuk menguji multikolinieritas dengan melihat nilai tolerance dan Variance Inflation Factor (VIF). nilai tolerance disetiap variabel independen berada dikisaran $0-1$, begitupun dengan nila VIF disetiap variabel independen <10,dapat disimpulkan bahwa dalam penelitian ini tidak mengalami multikolinieritas, sehingga salah satu syarat uji regresi berganda telah terpenuhi.

\section{Uji Hipotesis}

\section{a. Uji Parsial (t Test)}

Pengujian hipotesis penelitian yaitu menggunakan analisis regresi berganda (multiple regression analysis). Hasil dari perhitungan regresi diperoleh sebagai berikut:

\section{Tabel 4: Hasil Uji Hipotesis}

\begin{tabular}{|c|c|c|c|c|c|}
\hline \multirow[b]{2}{*}{ Model } & \multicolumn{2}{|c|}{ Unstandardized Coefficients } & \multirow{2}{*}{$\begin{array}{c}\begin{array}{c}\text { Standardized } \\
\text { Coefficients }\end{array} \\
\text { Beta }\end{array}$} & \multirow[b]{2}{*}{$\mathrm{t}$} & \multirow[b]{2}{*}{ Sig. } \\
\hline & B & Std. Error & & & \\
\hline (Constant) & $\begin{array}{c}- \\
1.747 \\
\end{array}$ & 3,112 & & $-0,561$ & 0,577 \\
\hline TOTAL_KE & 0,485 & 0,063 & 0,666 & 7,713 & 0,000 \\
\hline TOTAL_SPM & 0,086 & 0,063 & 0,122 & 1,358 & 0,180 \\
\hline TOTAL_LOC & 0,133 & 0,060 & 0,197 & 2,220 & 0,031 \\
\hline SPMLOC & 0,003 & 0,001 & 0,298 & 2,145 & 0,037 \\
\hline KELOC & 0,003 & 0,001 & 0,302 & 2,358 & 0,021 \\
\hline
\end{tabular}

Sumber : Data primer yang diolah 2015

Regresi $\mathrm{H}_{1}$ dan $\mathrm{H}_{2}$ :

$\mathrm{Y}=\alpha+\beta 1 \mathrm{SPM}+\beta 2 \mathrm{KE}+\beta 3 \mathrm{LOC}+\mathrm{e}$

$\mathrm{Y}=-1,747+0,086 \mathrm{SPM}+0,485 \mathrm{KE}+0,133 \mathrm{LOC}+\mathrm{e}$

Regresi $\mathrm{H}_{3}$ : 


$$
\begin{aligned}
& \mathrm{Y}=\alpha+\beta 1 \mathrm{SPM}+\beta 2 \mathrm{KE}+\beta 3 \mathrm{SPMLOC}+\mathrm{e} \\
& \mathrm{Y}=3,221+0,086 \mathrm{SPM}+0,485 \mathrm{KE}+0,003 \mathrm{SPMLOC}+ \\
& \mathrm{e} \\
& \text { Regresi } \mathrm{H}_{4}: \\
& \mathrm{Y}=\alpha+\beta 1 \mathrm{SPM}+\beta 2 \mathrm{KE}+\beta 3 \mathrm{KELOC}+\mathrm{e} \\
& \mathrm{Y}=3,560+0,086 \mathrm{SPM}+0,485 \mathrm{KE}+0,003 \mathrm{KELOC}+\mathrm{e}
\end{aligned}
$$

1) Pengujian hipotesis 1 .

Berdasarkan tabel 4, Sistem Pengendalian Manajemen memiliki nilai koefisien regresi sebesar 0,086dengan signifikansi sebesar $0,180>\alpha 0.05$ sehingga variabel Sistem Pengendalian Manajemen terbukti berpengaruh negatif signifikan terhadap variabel Kinerja. Jadi, hipotesis 1 ditolak.

\section{2) Pengujian hipotesis 2 .}

Berdasarkan tabel 4, variabel Kecerdasan Emosional memiliki nilai koefisien regresi sebesar 0,485dengan signifikansi sebesar $0,000<\alpha 0.05$ sehingga variabel Kecerdasan Emosional independen terbukti berpengaruh positif signifikan terhadap Kinerja. Jadi, hipotesis 2 diterima.

3) Pengujian hipotesis 3.

Berdasarkan tabel 4, Variabel Pemoderasi Locus of Control terhadap Sistem Pengendalian Manajemen memiliki nilai koefisien regresi sebesar 0,003dengan signifikansi sebesar $0,037<\alpha 0,05$ sehingga variabel Locus of Control terbukti memberi berpengaruh Sistem Pengendalian Manajemen terhadap kinerja. Jadi, hipotesis 3 diterima.

4) Pengujian hipotesis 4.

Berdasarkan tabel 4, Variabel Pemoderasi Locus of Control terhadap Kecerdasan Emosional memiliki nilai koefisien regresi sebesar 0,003dengan signifikansi sebesar $0,021<\alpha 0,05$ sehingga variabel Locus of Control terbukti memberi berpengaruh Kecerdasan Emosional terhadap Kinerja. Jadi, hipotesis 4 diterima.

Tabel5: Ringkasan Hasil Pengujian Hipotesis

\begin{tabular}{|c|l|c|}
\hline Kode & \multicolumn{1}{|c|}{ Hipotesis } & Hasil \\
\hline $\mathrm{H}_{1}$ & $\begin{array}{l}\text { Sistem Pengendalian } \\
\text { Manajemen } \quad \begin{array}{r}\text { Ditolak } \\
\text { berpengaruh } \\
\text { positif terhadap Kinerja ATC }\end{array}\end{array}$ & \\
\hline $\mathrm{H}_{2}$ & $\begin{array}{l}\text { Kecerdasan Emosional } \\
\text { Berpengaruh positif terhadap } \\
\text { Kinerja ATC }\end{array}$ & Diterima \\
\hline $\mathrm{H}_{3}$ & $\begin{array}{l}\text { Locus of Control berpengaruh } \\
\text { terhadap hubungan Sistem } \\
\text { Pengendalian Manajemen } \\
\text { terhadap Kinerja }\end{array}$ & Diterima \\
\hline $\mathrm{H}_{4}$ & \begin{tabular}{l} 
Locus of Control berpengaruh \\
\hline
\end{tabular} & Diterima \\
\hline
\end{tabular}

\begin{tabular}{|l|lr|l|}
\hline & $\begin{array}{l}\text { terhadap } \\
\text { Kecerdasan } \\
\text { terhadap Kinerja }\end{array}$ & hubungan \\
Emosional & & \\
\hline
\end{tabular}

\section{b. Uji Koefisien Determinasi ( $\mathbf{U j i} \mathbf{R}^{\mathbf{2}}$ )}

Uji koefisien Determinasi $\left(\mathrm{Uji}^{2} \mathrm{R}^{2}\right.$ dilakukan untuk mengetahui seberapa besar kemampuan variabel dependen penelitian (Variabel Kinerja) dapat dijelaskan oleh variabel independen penelitian (Sistem Pengendalian Manajemen, Kecerdasan Emosional, Locus of Control). Hasil uji koefisien Determinasi (uji $\mathrm{R}^{2}$ ) dapat dilihat pada output Model Summary dari hasil analisis regresi berganda. Hasil Uji koefisien Determinasi (Uji $\mathrm{R}^{2}$ ) diketahui hasilnya sebagai berikut:

Tabel 5: Hasil uji Koefisien Determinasi $\left(\mathbf{U j i}^{\mathbf{2}}\right)$

\begin{tabular}{|l|r|r|r|r|}
\hline Model & R & R Square & $\begin{array}{c}\text { Adjusted } \\
\text { R Square }\end{array}$ & $\begin{array}{c}\text { Std. Error } \\
\text { of the } \\
\text { Estimate }\end{array}$ \\
\hline 1 &, $824^{\mathrm{a}}$ &, 679 &, 661 & 1,895 \\
\hline
\end{tabular}

Pada tabel 5 diatas menerangkan bahwa nilai Adjusted $R$ Square sebesar 0.661 atau 66,1\%, maka variabel Kinerja dapat dijelaskan oleh variabel Sistem Pengendalian Manajemen (SPM), Kecerdasan Emosional (KE), serta Locus of Control sebesar $66,1 \%$. Kemudian sisanya sebesar $33,9 \%$ dijelaskan oleh variabel lainnya yang tidak termasuk dalam

\begin{tabular}{|c|c|c|c|c|c|c|}
\hline \multicolumn{2}{|c|}{ Model } & $\begin{array}{l}\text { Sum of } \\
\text { Squares }\end{array}$ & df & $\begin{array}{l}\text { Mean } \\
\text { Square }\end{array}$ & F & Sig. \\
\hline \multirow[t]{3}{*}{1} & Regression & 410,053 & 3 & 136,684 & 38,080 & .000 \\
\hline & Residual & 193.827 & 54 & 3,589 & & \\
\hline & Total & & 57 & & & \\
\hline
\end{tabular}
penelitian ini.

\section{c. Uji Simultan (Uji F)}

Hasil uji Simultan F (uji F) akan disajikan sebagai berikut:

Tabel 6: Hasil uji Statistik F (Uji F)

Hasil uji simultan F (uji F) dapat dilihat pada output ANOVA dari analisis regresi berganda diatas. Hasil uji $\mathrm{F}$ diatas menunjukan nilai $\mathrm{F}$ sebesar 38.080 dengan tingkat signifikansi sebesar 0,000. Perlu diketahui bahwa jika tingkat signifikansi lebih kecil daripada 0,05 atau $5 \%$ maka $\mathrm{H}_{\mathrm{a}}$ diterima dan $\mathrm{H}_{0}$ ditolak, sedangkan jika tingkat signifikansi lebih besar daripada 0,05 maka $\mathrm{H}_{0}$ diterima dan $\mathrm{H}_{\mathrm{a}}$ ditolak. Tingkat signifikansi diatas terbukti lebih kecil dari 0,05 maka dapat disimpulkan bahwa variabel Sistem Pengendalian Manajemen, Kecerdasan Emosional dan 
Locus of Control berpengaruh secara bersama-sama terhadap kinerja para staff ATC di lingkungan Perum LPPNPI AirNav Indonesia.

\section{Pembahasan}

\section{Pengaruh Sistem Pengendalian Manajemen terhadap Kinerja ATC}

Berdasarkan hasil penelitian membuktikan nilai sig sebesar 0,180 yang berarti diatas nilai alpha 0,05 menunjukan bahwa hipotesis yang diajukan ditolak. Hal ini sejalan dengan penelitian terdahulu yang dilakukan oleh Chow et al. (1999), menjelaskan bahwa sistem pengendalian manajemen berpengaruh secara signifikan sebagai variabel independen terhadap kinerja tetapi tidak secara interaksi mempengaruhi kinerja terutama pada institusi yang bergerak dalam sektor non profit.

Dengan metode penelitian interview menunjukan sistem pengendalian manajemen tidak berpengaruh positif terhadap kinerja ATC:

Kinerja seorang ATC ditentukan berdasarkan lama dia bekerja , semisal masa bakti orang tersebut telah bekerja seorang ATC. Instrumen yang dipergunakan berupa pencatatan berupa logbook yang di isi setiap kali dia bekerja.Instrumen Kinerja langsung berpengaruh sih enggak mas itukan sebagai bukti aja kalo kita udah ngontrol. (Interview 1)

Berdasarkan hasil peneilitan tersebut, menunjukan bahwa Instrumen pengukuran kinerja secara langsung tidak berpengaruh kepada kinerja individu ATC, namun berdasarkan paparan diatas instrumen pengukuran kinerja dijadikan sebagai poin penting dari Perum LPPNPI AirNav Indonesia.

\section{Pengaruh Kecerdasan Emosional terhadap Kinerja ATC \\ Variabel kecerdasan emosional memiliki nilai} signifikan sebesar 0,000 atau lebih kecil dari nilai alpha, hal itu dengan jelas menunjukan bahwa hipotesis kedua diterima, seperti penelitian terdahulu oleh Cooper dan Sawaf (1999), membuktikan bahwa kecerdasan emosional menyumbang persentase yang lebih besar dalam kemajuan dan keberhasilan masa depan seseorang, dibandingkan dengan kecerdasan intelektual yang biasanya diukur dengan Intelligent Quotient (IQ), kemudian hasil penelitian ini juga mendukung penelitian yang telah dilakukan sebelumnya oleh hasil penelitian Wijaya (2007), Hidayati (2008), Winarno (2008) yang ketiganya menunjukan hasil yang sama pada responden yang berbeda mengenai hubungan Kecerdasan Emosional terhadap Kinerja yang berakhir pada prestasi.

Dengan metode penelitian interview menunjukan kecerdasan emosional berpengaruh positif terhadap kinerja ATC:
Berkaitan dengan reward, reward sih biasanya tambahan untuk penilaian karyawan, contohnya setiap tahun ada misal perusahaan untung, setiap karyawan dikasih bonus 5 kali gaji sesuai dengan jabatan itu, untuk hukuman atau punishment ada beberapa bedanya tergantung tingkat kesalahan setelah investigasi mas. (Interview 5)

Hal tersebut memperkuat penelitian terdahulu yang dilakukan oleh Yacub (2013) dimana individu yang memiliki kecerdasan emosional yang baik akan memiliki disiplin kerja yang baik pula.

\section{Pengaruh Locus of Controlterhadap hubungan antara Sistem Pengendalian Manajemen terhadap Kinerja.}

Variabel locus of control sebagai pemoderasi memiliki nilai signifikan sebesar 0,021 atau lebih kecil dari nilai alpha, hal itu dengan jelas menunjukan bahwa hipotesis ketiga diterima, hal tersebut memperkuat penelitian terdahulu yang dilakukan oleh Nadirsyah (2009), menjelaskan bahwa locus of control merupakan faktor karakteristik personal auditor (faktor internal) yang dapat mempengaruhi penyimpangan perilaku. Pada kasus kali ini locus of control Internal yang lebih berperan mempengaruhi sistem pengendalian manajemen karena ditemui hasil yang berbeda dengan hipotesis pertama yang lebih berperan locus of control eksternalnya.

Dengan metode penelitian interview menunjukan locus of control berhasil menjadi variabel pemoderasi sistem pengendalian manajemen terhadap kinerja ATC:

Menurut saya sih udah pas, ga perlu diribetin lagi kan kerjanya udah ribet, sikap waspada udah yang tinggi udah ditanamkan pada masing-masing ATC, lagipula perusahaan saat ini masih berorientasi pada non profit. (Interview 1)

\section{Locus of Control Berpengaruh terhadap Hubungan Kecerdasan Emosional terhadap Kinerja}

Variabel locus of control sebagai pemoderasi memiliki nilai signifikan sebesar 0,021 atau lebih kecil dari nilai alpha, dan memiliki nilai koefisien 0,003 yang menjelaskan hipostesis yang dibuat searah dengan hasil pengujian data yang keduanya merujuk kearah positif, hal itu dengan jelas menunjukan bahwa hipotesis keempat diterima. Kemudian semakin memperkuat penelitian yang dilakukan oleh Winarno (2008), Nadirsyah (2009) mengenai kecerdasan emosional sebagai salah satu penunjang prestasi kerja karyawan. Perusahaan-perusahaan perlu menciptakan kesadaran akan keseimbangan antara kecerdasan 
konfensional dengan kecerdasan emosi pada karyawan-karyawannya melalui pelatihan-pelatihan untuk menciptakan karyawan yang berprestasi tinggi sehingga produktivitas perusahaan makin meningkat. Dengan metode penelitian interview menunjukan locus of control berhasil menjadi variabel pemoderasi kecerdasan emosional terhadap kinerja ATC:

Kalo saya sih lebih ke motivasi mas, udah kepalang cinta sama kerjaan saya. Jadi saya tetap berusaha mengerjakan semaksimal mungkin.(Interview 1)

Lebih ke motivasi karena selain buat masa depan juga senantiasa cara beribadah kepada Allah SWT.(Interview 6)

\section{Simpulan}

\section{Simpulan}

Penelitian ini bertujuan untuk mencari kemungkinan masalah yang muncul pada profesi Air Traffic Controller terutama setelah proses pemisahan perusahaan umum yang mandiri. Berdasarkan hasil kuisoner yang diterima, dapat ditarik kesimpulan. Pertama, Sistem Pengendalian Manajemen tidak berpengaruh terhadap kinerja ATC di Perum LPPNPI AirNav Indonesia.Dariinterview diperoleh gambaran bahwa Awareness atau waspada dari masing-masing individu Air Traffic Controller itu sendiri sudah tinggi sehingga sistem pengendali yang melekat hanya sebagai pelengkap dan tidak berpengaruh secara positif terhadap kinerja mereka.Kedua, Kecerdasan Emosional berpengaruh Positif terhadap Kinerja ATC di Perum LPPNPI AirNav Indonesia.Ketiga, Locus of Control berpengaruh terhadap hubungan antara sistem pengendalian manajemen terhadap Kinerja.Adapun bentuk Locus of Control yang lebih dominan adalah yang bersumber dalam diri individu atau internal locus of control.Ketiga, Locus of Control berpengaruh terhadap hubungan Kecerdasan Emosional terhadap Kinerja.

\section{Implikasi Penelitian}

Penelitian ini mempunyai implikasi dalam bidang kedirgantaraan dan juga bidang pendidikan.Dari hasil penelitian ditemukan bahwa peningkatan Sarana dan Prasarana perhubungan udara menjadi keharusan dan bersifat mendesak, keseriusan kementerian perhubungan sangat diharapkan untuk merombak dunia penerbangan indonesia agar lebih tinggi kualitasnya. Contohnya sarana dan prasarana di bandara Ahmad Yani yang seharusnya lebih bisa ditingkatkan karena sudah sangat kelebihan kapasitas maupun usangnya sarana pendukung. Disamping itu, pemerintah perlu didorong cara membuat pelatihanpelatihan dibidang manajemen ATC. Misalnya dengan menciptakan akademi kedirgantaraan disetiap provinsi yang memiliki bandara internasional sehingga mereka dapat memenuhi kebutuhan akan SDM kedirgantaraan sendiri tanpa harus menunggu lulusan sekolah tinggi kedirgantaraan milik pemerintah pusat.Bagi pengelola Bandara perlu memberi edukasi terhadap kendalakendala yang mungkin terjadi sehingga menggangu penerbangan para konsumen.Disamping itu juga menciptakan gerakan bandara ramah penumpang.

\section{Keterbatasan Penelitian}

Penelitian ini tidak terlepas dari keterbatasan yang dimiliki, namun demikian diharapkan dapat memberikan bahan pertimbangan dalam praktek dan pengembangan berikutnya. Beberapa keterbatasan penelitian ini antara lain:

1. Sulitnya penulis untuk memperoleh data mengenai cerminan kinerja yang sebenar benarnya dilakukan oleh ATC karena tidak adanya pengukuran kinerja yang pasti oleh perusahaan itu sendiri, disamping aksesbilitas untuk menyebarkan kuisoner karena tersebarnya para petugas ATC di seluruh Indonesia dengan jumlah personil yang relatif sedikit di masing-masing unitnya.

2. Variabel Sistem Pengendalian Manajemen yang dijadikan topik utama oleh penulis kurang menjadi topik yang dimengerti maupun diharapkan untuk di tingkatkan oleh responden sehingga menimbulkan kurangnya pengaruh positif dengan variabel dependen yang ditentukan penulis yaitu kinerja itu sendiri.

\section{Saran}

Dengan mempertimbangkan keterbatasanketerbatasan yang ada, maka disarankan untuk penelitian yang akan datang memperhatikan hal-hal berikut :

1. Dengan hasil beragam terutama dalam hal latar belakang pendidikan para responden menunjukan penting nya variabel Kecerdasan Intelektual untuk dimasukan, sehingga dapat diketahui apakah profesi ATC harus mencapai tingkat pendidikan tertentu misalkan strata-1.

2. Sumber data dapat diperluas dengan data sekunder yang diperoleh dengan metode wawancara kepada responden untuk memperoleh data yang jelas mengenai kekurangan perusahaan dari sektor keuangan sehingga dapat diperoleh output yang dapat berguna bagi Perum LPPNPI AirNav itu sendiri.

3. Berdasarkan daripada banyak permintaan responden ketika melakukan proses penyebaran kuisoner, perlu diadakan penelitian yang lebih mendalam lagi terutama pada aspek-aspek seperti Kesejahteraan, Status Kepegawaian, dan 
lain-lain yang tidak bisa lebih mendalam hanya melalui penelitian ini.

\section{Daftar Pustaka}

[1] Barling, J., Slater, F., \& Kelloway, E. K. 2000. Transformational leadership and emotional intelligence: an exploratory study. Leadership \& Organizational Development Journal, 21(3), 157-161.

[2] Baron \& Byrne. (1994). Social Psychology : Understanding Human Interaction (6th edition). USA: Needham Heights Allyn \& Bacon Inc.

[3] Bernardin, John H., dan Russel, Joyce. 1993. Human Resources Management: An Experiental Approach. Jakarta: Gramedia Pustaka.

[4] Birnberg, Turopolec, and S.M. Young. 1983. The Organizational Contex of Accounting". Accounting, Organizationals and Society 28: 97-126.

[5] Budiman, Jerry. 2013. “Analisis Beban Kerja Air Traffic Controller Bandara Menggunakan Metode NASA-TLX'.Jurnal Teknik Industri FT USU Vol 3, No. 3, Oktober 2013.

[6] Chow, C., Shield, M., and Chan, Y. 1999. The Effects of Management Controls and National Culture on Manufacturing Performance: An Experimental Investigation. Accounting, Organization and Society, 16, 209-226.

[7] Fisher, J. 1995. Contingency-Based Research on Management Control Systems: Categorization by Level of Complexity. Journal of Accounting Literature 14:24-5.3

[8] Ghozali, I. 2009. "Aplikasi Analisis MultiVariate dengan Program SPSS". Semarang:Badan Penerbit Universitas Diponegoro.

[9] Gibson, Ivancevich, Donelly, and Konopaske. 2003. Organization: Behavior, Structure, Processes, Eleventh Edition: McGraw Hill.

[10] Goleman, D. 2002. Primal leadership: Realizing the power of emotional intelligence. Boston: Harvard Bussiness School Press.

[11] Heider, F. 1958. Psikologi Hubungan Interpersonal. New York: Wiley.

[12] http://indokonsultan.com/konsultan-appraisalappraisal-consultant-penilai-penilaianperformance-appraisalkjpp-jasa-penilai-asset/ diakses 02 Agustus 2015 21:00 WIB

[13] Kren, L., 1992, Budgetary Participation and Managerial Performance The Impact of Information and Environment Volatility. The Accounting Review 3: 511 - 526.
[14] Mangkunegara, AA. Anwar Prabu. 2008. Perencanaan dan Pengembangan Sumber Daya Manusia. Cetakan Ketiga. Bandung: PT. Rafika Aditama. Remaja Rosdakarya.

[15] Modassir, Atika. 2008. "Relationship of Emotional Intelligence with Transformational Leadership and Organizational Citizenship Behavior Journal “. International Journal of Leadership Studies . Volume 4.

[16] Nadirsyah. 2009. Locus of Control, Time Budget Pressure Dan Penyimpangan Perilaku Dalam Audit. Jurnal Telaah \& Riset Akuntansi Volume 2, Nomor 2, Juli 2009, hlm. 104-116

[17] Republik Indonesia. 2012. Peraturan Pemerintah No. 77 Tahun 2012 tentang Perusahaan Umum (Perum) Lembaga Penyelenggaraan Pelayanan Navigasi Penerbangan Indonesia. Kementerian Perhubungan. Jakarta.

[18] Simanjuntak, Payaman J. 2005. Manajemen dan Evaluasi Kinerja. Jakarta: FE UI.

[19] Snodgrass. 1988. Culture and Control: A Survey, Accounting, Organizations and Society pp. 447-464

[20] Salovey, P., \& Mayer, J. 1990. Emotional intelligence. Imagination, Cognition, and Personality, 9, 185-211.

[21] Setyawan, P. 2013. Radar Bandara Adisutjipto kembali alami gangguan sistem.Sindonews.com 16 Sepember.

[22] http://daerah.sindonews.com/read/783766/22/ra dar-bandara-adisutjipto-kembali-alamigangguan-sistem-1379335415

[23] Sugiyono. 2009. Metode Penelitian Bisnis. Bandung:Alfabeta.

[24] Suryani.2005. Komunikasi Terapeutik : teori dan praktik. Jakarta : EGC

[25] Wijaya, Tony. 2007. Pengaruh Organizational Citizenship Behaviour Terhadap Kinerja anggota kepolisian. Jurnal Manajemen dan Bisnis, Volume 6, Nomor 1, tahun 2007, hlm.53

[26] Winarno, Jacinta. 2008. Emotional Inteligence Sebagai Salah Satu Faktor Penunjang Prestasi Kerja. Jurnal Manajemen, Volume 8, Nomor 1, November 2008

[27] Wiyantoro, L.S dan Arifin Sabeni. 2007. Hubungan Antara Sistem Pengendalian Manajemen Dengan Perilaku Dysfunctional: Budaya Nasional Sebagai VariabelModerating, Makalah Simposium Nasional Akuntansi X Makassar: 1-23. 